\title{
Assessment of Cytotoxic Activity of Calotropis Procera's Extracts Using Artemia Salina Assay
}

\author{
Asoso $\mathrm{OS}^{1 *}$, Oladunmoye $\mathrm{M} \mathrm{K}^{2}$ and Ogundare $\mathrm{AO}^{2}$ \\ ${ }^{1}$ Department of Biological Sciences, Afe Babalola University, Ado-Ekiti, Ekiti State, Nigeria \\ ${ }^{2}$ Department of Microbiology, Federal University of Technology, Akure, Ondo State, Nigeria
}

*Corresponding author: Asoso O S, Department of Biological Sciences, Ado-Ekiti, Nigeria

\begin{tabular}{|c|c|}
\hline ARTICLE INFO & ABSTRACT \\
\hline $\begin{array}{l}\text { Citation: Asoso OS, Oladunmoye MK, } \\
\text { Ogundare AO. Assessment of Cytotoxic } \\
\text { Activity of Calotropis Procera's Extracts } \\
\text { Using Artemia Salina Assay. Biomed } \\
\text { J Sci \& Tech Res 18(5)-2019. BJSTR. } \\
\text { MS.ID.003224. } \\
\text { Keywords: Calotropis Procera; Cytotox- } \\
\text { icity; Extracts; Brine Shrimps }\end{array}$ & $\begin{array}{l}\text { The essence of the present study is to focus on the cytotoxicity of the aqueous and } \\
\text { solvent (acetone, methanol and ethanol) of the medicinal plant (Calotropis procera) } \\
\text { belonging to the family Apocynaceae. Brine shrimp lethality bioassay method was } \\
\text { established for the present study and the cytotoxicity was reported in terms of lethality } \\
\text { concentration }\left(\mathrm{LC}_{50} \text { ) The shrimps were hatched and active shrimps were collected and }\right. \\
\text { used for the assay. Ten active naupilli were added to the } 1 \mathrm{ml} \text { of the diluted extracts, } \\
\text { concentration was varied from } 10,100,1000 \mu \mathrm{g} / \mathrm{ml} \text {. The surviving (larvae) shrimps } \\
\text { were counted after } 24 \mathrm{hrs}, 48 \mathrm{hrs} \text { and lethality concentration } \mathrm{LC}_{50} \text { was also assessed. It } \\
\text { was observed that the methanol extract of Calotropis procera leaf have weak cytotoxic } \\
\text { compounds while other extracts were able to cause } 45 \% \text { mortality of brine shrimp } \\
\text { larvae after } 48 \text { hours. The present study supports that brine shrimp bioassay is simple, } \\
\text { reliable and convenient method for assessment of bioactivity and cytotoxicity of } \\
\text { medicinal plants. The cytotoxicity exhibited by the crude extracts were promising and } \\
\text { this indicates the presence of potent bioactive compounds. }\end{array}$ \\
\hline
\end{tabular}

\section{Introduction}

In modern era, the medicinal plants have been gradually replaced by synthetic drugs. But of recent, it is being realized that several diseases were found to develop drug resistance to synthetic drugs and also responsible for many of adverse effects. The present study concentrates on the cytotoxic activity of the folklore claimed plant Calotropis procera using brine shrimp lethality bioassay which is based on the ability to kill cultured brine shrimp (Artemia salina). Artemia salina the brine shrimp is an invertebrate component of the fauna of salina aquatic and marine ecosystem. It plays an important role in the energy flow of the food chain [1]. Calotropis procera was formerly placed in the family Asclepiadaceae (the milkweed family), which is now considered a subfamily of the Apocynaceae.

\section{Materials and Methods}

\section{Collection of Plant Samples}

Apparently healthy plant namely C. procera were collected from Ado-Ekiti, Ekiti State Nigeria.

\section{Preparations of Plant Extracts}

The plant parts leaves and stem were air-dried for 5 weeks at room temperature $\left(25 \pm 2{ }^{\circ} \mathrm{C}\right)$ and then ground to powder with a mechanical grinder (Thomas Wiley machine, model 5 USA). Powders (200g) of each plant were extracted with 1litre of sterile aqueous water, ethanol, methanol and acetone separately at room temperature $\left(25 \pm 2{ }^{\circ} \mathrm{C}\right)$. They were labeled as crude extracts.

\section{Cytotoxicity Assay}

This assay is carried out by using Brine Shrimp (Artemia salina L.) model [2]. Brine shrimp eggs were collected and placed in one side of a small tank divided by a net containing brine salt solution at a temperature around $37^{\circ} \mathrm{C}$ equipped with constant oxygen supply by using an air pump for hatching. The method of Artemia Salina was used to analyze the cytotoxicity assay, whereby the concentration of the extracts were varied as follows; $10,100,1000 \mu \mathrm{g} / \mathrm{ml}$. The positive control and the negative control were $\left(\mathrm{DMSO}_{4}\right)$ and (brine solution without extracts) respectively. 


\section{Results}

\section{Cytotoxicity Assay of The Active Extracts of Calotropis Procera Leaf and Stem}

The number of shrimps that were able to survive after 24 hours and 48 hours were enumerated.

\section{Cytotoxicity Assay of The Active Extracts of Calotropis Procera Leaf and Stem After 24 Hours}

Acetone extract had the highest mortality rate, followed by the methanol stem and aqueous stem extracts whereas there was no death of the brine shrimp in methanol leaf extract (Figure 1).



Figure 1: Mortality rate of Brine shrimp exposed to extracts of Calotropis procera at different concentration after 24 hours.

Key: AS-Aqueous Stem, MS- Methanol Stem, ML- Methanol Leaf, AC- Acetone Leaf,

CC- Negative Control And CCC- Positive Control.

\section{Cytotoxicity Assay of The Active Extracts of Calotropis Procera Leaf and Stem After 48 Hours}

At 48 hours, the mortality rate increases in all the extracts except methanol leaf extract that had no death of the brine shrimp even at 24 hours (Figure 2).

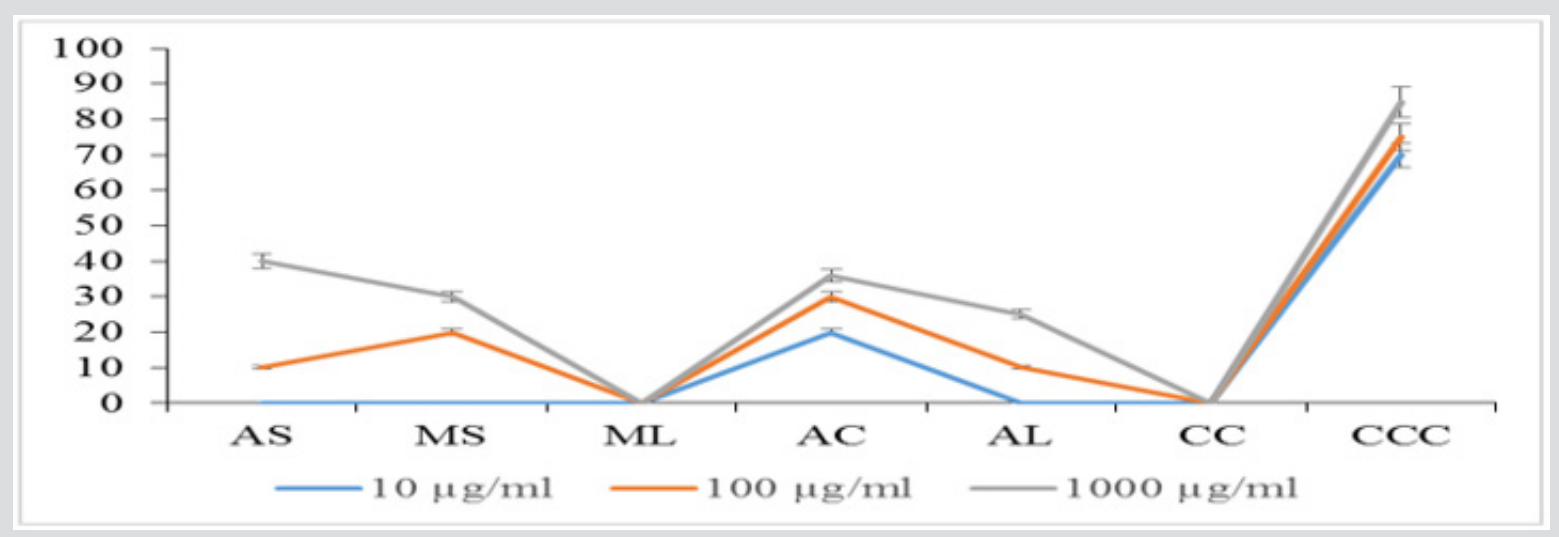

Figure 2: Mortality rate of Brine shrimp exposed to extracts of Calotropis procera at different concentration after 48 hours. Key: AS-Aqueous Stem, MS- Methanol Stem, ML- Methanol Leaf, AC- Acetone Leaf, CC- Negative Control And CCC- Positive Control. 


\section{The Lethality Dose $\left(\mathrm{LD}_{50}\right)$ Values $(\mu \mathrm{g} / \mathrm{Ml})$ of Active Extracts}

The lethality dose showed that the CC (positive control) which is brine solution without extracts; had the highest mortality rate which gave the lowest value of $\mathrm{LD}_{50}$ (Table 1 ).

Table 1: The lethality dose $\left(\mathrm{LD}_{50}\right)$ values $(\mu \mathrm{g} / \mathrm{ml})$ of various extracts required to killed $50 \%$ brine shrimp after $24 \mathrm{hrs}$.

\begin{tabular}{|c|c|}
\hline Extracts & Concentration $(\mu \mathrm{g} / \mathbf{m l})$ \\
\hline AQS & $448.64^{\mathrm{a}} \pm 1.20$ \\
\hline MS & $334.10^{\mathrm{b}} \pm 2.09$ \\
\hline ML & $500.0^{\mathrm{a}} \pm 0.00$ \\
\hline ACL & $459.67^{\mathrm{a}} \pm 4.02$ \\
\hline AQL & $445.90^{\mathrm{a}} \pm 1.33$ \\
\hline CC & $500.0^{\mathrm{a}} \pm 0.00$ \\
\hline CCC & $156.98^{\mathrm{c}} \pm 0.96$ \\
\hline
\end{tabular}

Key: AQS-Aqueous Stem, MS- Methanol Stem, ML- Methanol Leaf, ACL- Acetone Leaf, AQL- Aqueous Leaf

CC- Negative Control And CCC- Positive Control.

\section{The Lethality Dose $\left(\mathrm{LD}_{50}\right)$ Values $(\mu \mathrm{g} / \mathrm{Ml})$ of Active Extracts}

The result showed that the CCC (positive control: brine solution without extracts); with the highest mortality rate had the lowest value of $\mathrm{LD}_{50}$ (Table 2).

Table 2: The lethality dose $\left(\mathrm{LD}_{50}\right)$ values $(\mu \mathrm{g} / \mathrm{ml})$ of various extracts required to killed $50 \%$ brine shrimp after $48 \mathrm{hrs}$.

\begin{tabular}{|c|c|}
\hline Extracts & Concentration $(\mu \mathrm{g} / \mathrm{ml})$ \\
\hline AS & $347.14^{\mathrm{b}} \pm 3.10$ \\
\hline MS & $214.90^{\mathrm{c}} \pm 2.19$ \\
\hline ML & $500.0^{\mathrm{a}} \pm 0.00$ \\
\hline AC & $203.67^{\mathrm{c}} \pm 0.03$ \\
\hline AL & $441.10^{\mathrm{a}} \pm 3.81$ \\
\hline CC & $500.0^{\mathrm{a}} \pm 0.00$ \\
\hline CCC & $126.11^{\mathrm{c}} \pm 1.02$ \\
\hline
\end{tabular}

KEY:

AS: Aqueous Stem

MS: Methanol Stem

ML: Methano Leaf

AC: Acetone Leaf

AL: Aqueous Leaf

CC: Negative Control; just the brine solution without extract

CCC: Positive Control; brine solution with $2 \mathrm{ml}$ of $5 \% \mathrm{DMSO}_{4}$

\section{Discussion}

This assay plays an important role in the energy flow of the food chain and it can be used in the laboratory bioassay in order to determine the toxicity by the estimation of the medium lethality concentration LC50 [3] Mortality increased gradually with the increase in concentration of the test samples. This difference in the toxicity results may be probably due to the chemical complexity of the crude extracts which seemed to be essential for the bioavailability of the active constituents of the examined plant [4]. There was a gradual increase in the percentage of the mortality rate with the increase in concentration of the extract; this finding is in support with Ramachandran et al. The brine shrimp lethality bioassay represents a rapid, in expensive and simple bioassay for testing plant extracts bioactivity which in most cases correlates reasonably well with cytotoxic and anticancer properties [5]. Generally, it can be concluded that the extracts contain potent cytotoxic compounds except the methanol leaf extract.

\section{References}

1. Lewan LM, Anderson, Morales PG (1992) Use of Artemia Salina in toxicity testing. Altern Lab Anim 20(2): 297-301.

2. Mentor R, Hamidi B, Jovanova T, Kadifkova P (2014) Toxicological evaluation of the plant products using Brine Shrimp (Artermia salina L.) Model Macedonian Pharmaceutical Bulletin 60(1): 9-18.

3. McLaughlin JL, Chang CJ, Smith DL (1993) Simple bench-top bioassays (brine shrimp and potato discs) for the discovery of plant antitumor compounds. A Chem Sco Sympos Ser 534: 112-134.

4. Meyer BN, Ferrigni NR, Putnam JE, Jacobsen LB, Nichols DE, et al. (1982) Brine shrimp: A convinent general bioassay for active plant constituents. Planta Med 45(5): 31-34.

5. Miller L C, Tainter M C (1994) Estimation of LD50 and its error by means of logarithmic-probit graph paper. Proceding in Society of Experimental Biology of Medicine 57(2): 261-264. 


\section{ISSN: 2574-1241}

DOI: 10.26717/BJSTR.2019.18.003224

Asoso OS. Biomed J Sci \& Tech Res

(C) This work is licensed under Creative

Submission Link: https://biomedres.us/submit-manuscript.php



